\title{
Coblation Turbinate Reduction in Patient with Nasal Obstruction
}

\author{
Chang Mook Park and Jung Soo Kim \\ Department of Otorhinolaryngology-Head and Neck Surgery, Kyungpook National University Hospital, School of Medicine, \\ Kyungpook National University, Daegu, Korea
}

\section{만성 코막힘 환자에서 Coblation 하비갑개 축소술}

\author{
박 창 묵·김 정 수 \\ 경북대학교 의학전문대학원 이비인후-두경부외과학교실
}

\author{
Received April 1, 2013 \\ Accepted July 2, 2013 \\ Address for correspondence \\ Jung Soo Kim, MD, PhD \\ Department of Otorhinolaryngology- \\ Head and Neck Surgery, \\ Kyungpook National University \\ Hospital, School of Medicine, \\ Kyungpook National University, \\ 130 Dongdeok-ro, Jung-gu, \\ Daegu 700-721, Korea \\ Tel $+82-53-420-5783$ \\ Fax $+82-53-423-4524$ \\ E-mailssookim@knu.ac.kr
}

\begin{abstract}
Chronic nasal obstruction is a common symptom and usually comes from mucosal disease associated with turbinate hypertrophy. Diverse surgical treatments have been used to improve chronic nasal obstruction in patients with inferior turbinate hypertrophy. However, there is no common consensus about the values of the various methods. The ideal turbinate surgery should effectively decrease the volume of turbinate, keep physiologic function of nose, and avoid complications. Recently, office-based inferior turbinate reduction using radiofrequency energy has been gaining popularity. In this article, the efficacy and morbidity of coblation turbinate reduction for nasal obstruction will be reviewed.
\end{abstract}

Korean J Otorhinolaryngol-Head Neck Surg 2013;56:754-8

Key Words Inferior turbinate hypertrophy · Nasal obstruction · Radiofrequency.

\section{서 론}

만성적인 코막힘은 외비와 비중격 변형, 비용 혹은 하비갑개 비대와 관련된 점막질환에 의해 발생한다. ${ }^{1)}$ 이 중 하비갑개 비 대는 알레르기 비염, 혈관 운동성 비염 등 여러 형태의 비염이 원인으로, 만성적인 자극이 정맥총의 울혈 및 점막 내 섬유화 와 염증과정을 유도하고 이러한 상태가 지속되어 비갑개 점막 의 비후가 발생한다. ${ }^{2)}$

하비갑개 비대의 치료에는 일반적으로 국소 스테로이드의 비강 내 분무, 항히스타민제나 비점막 혈관수축제의 경구 복 용 등의 약물치료가 우선시 된다. 그러나 내과적 치료에 실패 한 만성적으로 비대해진 하비갑개는 수술적 치료가 필요하 다. ${ }^{3-5)} 19$ 세기 후반부터 현재까지 다양한 치료법들이 소개되었 으며 하비갑개 절제술, 점막하 절제술, 전기 소작법, 화학 소작 법, 외측 전위, 스테로이드 점막하 주입술, 비디안 신경절제술, 냉동요법, 레이저 절제술, powered instruments 등이 있다.') 이
들 술식은 각각의 치료 장점이 있으나 통증, 출혈, 가피형성, 건조감, 감염, 유착 등의 술 후 합병증이 흔하여,") 치료 효과가 영구적이며, 외래에서 간편하게 시행할 수 있고, 불편감이나 부작용을 최소화하며, 비강 내 습도와 온도 조절 등의 하비갑 개의 생리적 기능을 보존할 수 있는 이상적인 하비갑개 수술 을 필요로 한다. ${ }^{8}$

최근 소개된 무선주파(radiofrequency)를 이용한 하비갑개 축소술은 효과적이면서 최소한의 침습적인 치료 방법으로 인 정되고 있다.1.10) 무선주파 에너지는 오래 전부터 여러 다양한 의 료분야에서 광범위하게 이용되어 왔으며, 이비인후과 영역에 적용된 것은 1997년 Powell 등1에에 의해 처음으로 소개되어, 오늘날에는 이용의 편의성과 최소 침습성 등의 특징으로 단순 코골이나 수면장애 질환, 그리고 편도비대 등 비과영역에서 널 리 사용되고 있다. ${ }^{12,13)}$ 


\section{본 론}

\section{원 리}

무선주파 에너지를 이용한 기술을 coblation(controlled ablation) technology라고 하며 이는 $100 \mathrm{kHz}\left(\right.$ Coblator $^{\mathrm{TM}}$, Arthrocare, Sunnyvale, CA, USA)의 주파수를 이용한다.

Coblation 하비갑개 축소술의 원리는 절연이 안된 전극 끝 에서 발생한 무선주파가 전류 방향을 계속 바꾸어 생리식염 수 같은 전도매개체 내에 존재하는 주변 조직의 이온을 진동 시켜 마찰열을 발생시키는 것이다. ${ }^{14)}$ 기존의 전기소작기를 이 용한 조직 절개 및 소작시 $500^{\circ} \mathrm{C}$ 정도의 고열이 발생하여 주 위의 열 손상이 큰 데 비하여, coblation 하비갑개 축소술시 발생하는 마찰열은 $100^{\circ} \mathrm{C}$ 이하로 고열에 의한 점막섬모운동능 의 저하 및 주변정상조직의 손상을 최소화 할 수 있어 점막의 생리기능 및 상피를 보존하여 회복이 빠르다는 장점을 가지고 있다. ${ }^{5,15}$

\section{수술방법}

Coblation 하비갑개 축소술은 매우 간단한 작업으로 외래 혹은 일일수술실에서 국소마취 하에 시행 가능하다. ${ }^{16}$ 환자는 반좌위(semifowler position)를 취하고 2\% lidocaine과 1 : 100000 epinephrine을 섞은 용액을 솜 조각에 묻혀 비강 내 에 약 10 분간 넣어두어 1 차적인 마취를 하고 비강 내 시야를 확보한다. Midazolam 등의 진정제 사용은 필요없으며, $1 \%$ lidocaine과 $1: 100000$ epinephrine을 섞은 용액을 이용하여 하비갑개에 침윤마취를 함으로써 환자는 큰 불편함 없이 수술 을 받을 수 있다. ${ }^{17)}$

앞서 기술했듯이, 무선주파 에너지는 전도매개체 내에 존재 하는 전해질을 진동시켜 마찰열을 발생하므로 생리식염수를 이용해 하비갑개 점막 하 조직을 충분히 부풀리는 것이 중요하 다. ${ }^{18)}$ 또한 이를 통해 소작할 때 발생 가능한 골부와 점막의 열 손상을 줄일 수 있다.

Coblation 기구[ReFlex 45 wand, Arthrocare(Sunnyvale, CA, USA)]를 사용하여 coblation 출력수준을 4 6(105 180 $\mathrm{W}$ )으로 세팅하고 길이 $10 \mathrm{~mm}$, 지름 $1 \mathrm{~mm}$ 의 활성 전극을 가 진 탐침(probe)을 양측 하비갑개 전단부의 내측과 아래 측에 총 두 군데씩 삽입한다. 내측으로 삽입된 활성 전극은 중비도 방향으로 비중격과 평행하게 진행하며, 아래 측으로 삽입된 활 성 전극은 하비갑개 골부의 촉감을 느끼며 비강저와 평행하게 후방으로 진행하면서 필요한 부위를 소작한다. ${ }^{17)}$ 탐침의 끝은 $10 \mathrm{~mm}$ 길이마다 세 개의 선이 표시되어 있어 술자는 활성 전 극의 삽입된 깊이를 추측할 수 있으며 내시경을 통해 소작부 위가 수축되는 것을 실시간으로 확인할 수 있다. ${ }^{14)}$
소작 후 삽입부위의 출혈을 감소시키기 위해 탐침을 하비갑 개에서 제거하기 전 coagulation 모드(출력수준: 3)로 지혈을 시도할 수 있으며 하비갑개 뒤쪽 비후가 심할 경우 하비갑개 뒤쪽을 보다 효과적으로 축소하기 위해 하비갑개를 외측 전 위시켜 수술 중 하비갑개 후단부를 정확히 볼 수도 있다. ${ }^{19)}$ 매 우 심한 하비갑개 비대나 비중격만곡 등 때문에 두 군데의 경 로(channeling)만으로는 적절한 위치에서 점막 하 소작이 어 려울 시, 하비갑개 전장에 걸쳐 내측과 하방 부위에 필요한 만 큼 탐침을 점막 하층에 삽입하여 소작할 수 있다.

적절한 소작시간은 점막 비대의 정도에 따라 조절되어야 하 나 일반적으로 10 초 이내로 충분하며 점막에 손상을 주지 않 도록 최대한 주의를 기울인 상태에서 점막 표면이 창백하게 변 할 경우 즉시 소작을 중단함으로써 적정시간을 가늠할 수 있다. ${ }^{20)}$

패킹은 필요 없으며 혈관수축제를 적신 솜 조각을 수분간 거치시키는 것만으로 수술을 완료할 수 있다. ${ }^{17)}$

\section{조직반응}

고온은 빠른 단백질 변성과 더불어 세포손상을 일으키며, 조직 파괴의 심한 정도는 온도와 노출된 시간에 비례한다. 조 직의 단백질을 변성시키기에 충분할 정도의 비교적 낮은 온도 $\left(50 \sim 90^{\circ} \mathrm{C}\right)$ 에서 적정 시간(하비갑개 점막이 창백하게 변성되기 전까지의 시간)동안 하비갑개 점막 내로 전달된 무선주파 에 너지는 국소적인 럭비공 모양의 병변을 만들게 되며 능숙하게 사용할 시 하비갑개 골부나 점막 그리고 주변 구조물의 손상 을 거의 예방할 수 있다. ${ }^{16,21,22)}$

고주파 에너지에 의해 발생한 점막 하 괴사 부위는 창상 치 유과정에 따라 대식세포가 증식, 활성화되며, 활성화된 대식 세포는 섬유모세포(fibroblast)를 자극하여 교원질을 생성하게 한다. 따라서 여러 종류의 비염환자에서 보이는 술잔세포와 기 저세포의 증식, 기저막의 비후를 포함한 점막의 비대와 점막 하 고유층의 부종, 호산구의 침윤, 분비샘의 비후, 해면체 조직 혈관 확장 등의 조직소견을 섬유조직과 육아조직으로 대체시 킴으로써 하비갑개 축소의 효과를 유도할 수 있다.2) 또한, 하 비갑개 점막과 골막이 유착되어 하비갑개 내의 혈류량이 줄어 들어 하비갑개는 알레르기항원, 바이러스, 자세변화 등 부종 을 일으키는 인자에 대한 민감도가 낮아진다. ${ }^{18)}$

\section{치료효과}

앞에서 설명한 조직반응으로 무선주파 에너지는 하비갑개 를 축소할 수 있고 하비갑개는 점막부종을 일으키는 여러 인 자들에 저항성을 가지게 되어 환자들의 주관적인 만성 코막 힘 증상은 호전된다.

Rhee 등 ${ }^{15)}$ 은 16 명의 하비갑개 비대 환자를 대상으로 한 co- 
blation 하비갑개 축소술 후 비기능의 변화에 관한 연구에서 술 후 2일부터 통계학적으로 의미 있게 코막힘에 대한 증상점 수가 추적기간(8주) 동안 호전됨을 보고했다. 또한, 음향 비강 통기도 검사에서 비강용적은 수술전보다 술 후 8주에 통계학 적으로 의미 있게 증가했으며, 사카린 수송시간이나 섬모운동 이 수술 후에도 정상범위로 잘 유지됨을 보고하였다.

Di Rienzo Businco 등 ${ }^{23)}$ 은 알레르기 비염 환자들에서 약물 치료만 시행한 그룹과 약물치료와 coblation 하비갑개 축소술 을 함께 시행한 그룹 간의 주관적 코막힘 호전 정도에 있어 통 계학적으로 유의한 차이가 있음을 보고했다.

Lin 등 ${ }^{24)}$ 이 발표한 약물치료에 반응이 없는 알레르기 비염 에서 시행한 coblation 하비갑개 축소술의 장기효과에 대한 연 구에서는, 5 년간 추적관찰을 시행한 101 명의 환자에서 수술 5 년 후의 코막힘에 대한 증상점수가 술 후 6개월에 비해 약간 상승하지만, 수술 전보다는 통계학적으로 의미 있게 감소하여 치료 효과가 장기간 유지됨을 보여주었다.

Coblation 하비갑개 축소술에 관한 대부분의 과거 논문들 은 하비갑개 비대에 따른 비강 통기성의 문제에 대해 초점을 맞추었으나, 알레르기 비염의 경우 항원에 대한 하비갑개 점막 의 과민반응이 알레르기 비염의 병태생리에서 가장 중요한 부 분이며 coblation 하비갑개 축소술시 신경섬유 및 혈관들이 파괴됨으로써 점막 고유층 내 반흔조직이 형성되어 술 후 점 막의 과민반응을 억제한다는 점을 근거로 알레르기 비염에 서 전형적인 비증상(코막힘, 콧물, 코가려움, 재채기, 눈가려움) 모두에 대한 효용성을 제시했다. ${ }^{17,18,23)}$

저자들의 경우에 환자 중 약물 치료시 비증상은 호전되었으 나 장기간의 약물 투여의 불편함을 호소하거나 약물 부작용 으로 coblation 하비갑개 축소술을 실시하였던 환자에서 코 막힘에 대한 증상점수가 술 후 6개월째 및 12 개월째에 통계적 으로 의미 있게 호전되었으며 6개월, 12 개월째 평균 개선 정도 는 각각 $58.1 \%, 37.2 \%$ 로(unpublished data) 지속성 알레르 기 비염 환자 중 약물요법에 효과는 있지만 반복되는 코증상 으로 인해 장기적인 약물 투여를 요하거나 약물 부작용이 있 는 경우 안전하면서도 유용한 대체 치료법 중의 하나로 생각 된다.

\section{수술관련 합병증}

Coblation 하비갑개 축소술의 합병증은 드물며, ${ }^{25)}$ 가장 흔한 부작용은 탐침 삽입 부위의 가피 생성이다(Fig. 1). 그 밖에 출 혈, 통증과 국소마취와 관련한 심계항진, 현기증 등이 간헐적으 로 발생할 수 있다.9) 그러나 대부분의 이런 합병증들은 자연적 으로 회복되거나 쉽게 조절된다.

Bäck 등 ${ }^{18}$ 은 coblation 하비갑개 축소술을 시행한 20 명의

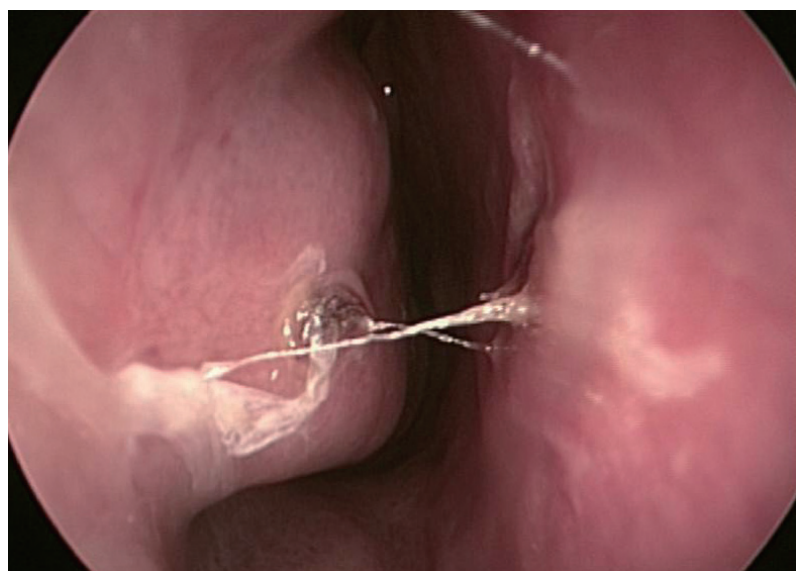

Fig. 1. Endoscopic intranasal examination revealing mild crust of probe insertion site (3 days postoperatively). No superficial mucosa damage of inferior turbinate was noted, after dressing of gelatin like nasal discharge.

환자에서 점막 손상, 출혈, 그리고 유착성의 가피형성은 전혀 나타나지 않았고 흔히 통증, 비루가 발생했으나 이는 수술 2일 후 자연적으로 회복됨을 보고했다.

약물치료에 반응이 없는 알레르기 비염 환자 108명에서 시 행한 coblation 하비갑개 축소술에 관한 연구에서 24명(22.2\%) 의 환자가 전상악부(premaxillary area)에 약간의 저린감을 호소했으나 무선주파 에너지가 발생할 때만 나타나는 일시적 인 증상이었고 그 외 가피, 출혈, 감염, 유착, 건조감 등의 합병 증은 나타나지 않았다고 기술했다. ${ }^{17)}$

저자들도 $1 \%$ lidocaine을 이용한 하비갑개의 침윤마취와 관련하여 심계항진이나 현기증 등의 부작용을 가끔 경험하였 으며, 이는 하비갑개의 혈류량이 풍부하여 국소마취와 관련한 심독성에 의한 일시적인 현상으로 수술을 중단한 경우는 없었 다. 또한 침윤마취를 위한 lidocaine의 농도를 $1 \%$ 에서 $0.5 \%$ 로 희석하여 수술을 진행했을 시에는 모든 경우에서 마취 부작 용이 발생하지 않았고 수술시 통증도 증가하지 않았다.

Coblation 하비갑개 축소술이 쉽고 간편하며 부작용이 적 은 수술이긴 하나, 에너지를 너무 과도하게 사용하거나 활성 전 극의 위치를 정확히 파악하지 못한 상황에서 시행하면 예기치 못한 장애를 남길 수 있어 주의가 필요하다(Figs. 2 and 3).

\section{결 론}

Coblation 하비갑개 축소술은 정상 구조물을 제거하지 않 고, 국소 마취하에 일일수술실이나 외래에서 간편히 시행할 수 있으며 술 후 패킹이 필요없다는 장점이 있다. 또한, 주위에 대 한 열 손상이 적고 점막의 생리기능 및 상피를 보존하여 회복 이 빠르다는 장점을 가지고 있다. 비록 장기적으로는 비갑개 비 대가 재발하는 경향을 보이지만 간편하게 반복 시술함으로써 
Fig. 2. Endoscopic postoperative views of inferior turbinate. If radiofrequency energy is given too much, severely adhesive crust could be occurred (one month postoperatively) (A). In severe complicated case, bony portion of the inferior turbinate is exposed through destruction of the mucosa(four months postoperatively) (B).
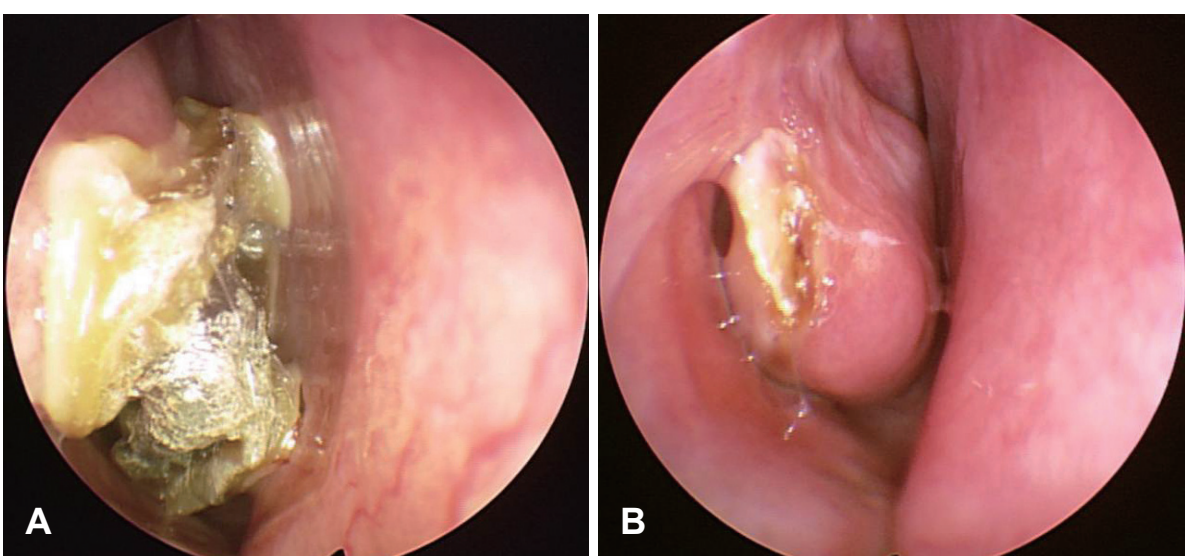

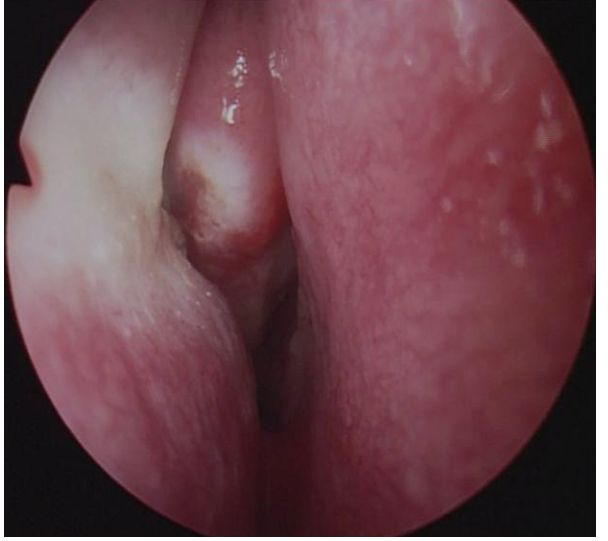

Fig. 3. Endoscopic intranasal image showing mucosal damage of middle turbinate. To avoid damage of surrounding structures, the location of active electrode should be identified just before ablation.

치료 효과를 유지할 수 있어 비폐색 환자에서 효과적으로 사 용될 수 있는 주요한 방법으로 판단된다.

\section{REFERENCES}

1) Jafek BW, Dodson BT. Nasal obstruction. In: Bailey BJ, Calhoun KH, Healy GB, editors. Head and Neck Surgery: Otolaryngology. 3rd ed. Philadelpia: Lippincott Williams \& Wilkins;2001. p.300-8.

2) Berger G, Gass S, Ophir D. The histopathology of the hypertrophic inferior turbinate. Arch Otolaryngol Head Neck Surg 2006;132(6): 588-94.

3) Sapçi T, Sahin B, Karavus A, Akbulut UG. Comparison of the effects of radiofrequency tissue ablation, $\mathrm{CO} 2$ laser ablation, and partial turbinectomy applications on nasal mucociliary functions. Laryngoscope 2003;113(3):514-9.

4) Friedman M, Tanyeri H, Lim J, Landsberg R, Caldarelli D. A safe, alternative technique for inferior turbinate reduction. Laryngoscope 1999;109(11):1834-7.

5) Hong SK, Yoon SO, Park SK, Son JY, Kim EA, Cho YH, et al. Laserassisted versus coblation-assisted partial turbinoplasty: comparison by their postoperative outcome. Korean J Otolaryngol-Head Neck Surg 2002;45(6):589-93.

6) Hol MK, Huizing EH. Treatment of inferior turbinate pathology: a review and critical evaluation of the different techniques. Rhinology 2000;38(4):157-66.

7) Elwany S, Harrison R. Inferior turbinectomy: comparison of four techniques. J Laryngol Otol 1990;104(3):206-9.
8) Chang CW, Ries WR. Surgical treatment of the inferior turbinate: new techniques. Curr Opin Otolaryngol Head Neck Surg 2004;12 (1):53-7.

9) Harsten G. How we do it: radiofrequency-turbinectomy for nasal obstruction symptoms. Clin Otolaryngol 2005;30(1):64-6.

10) Nease CJ, Krempl GA. Radiofrequency treatment of turbinate hypertrophy: a randomized, blinded, placebo-controlled clinical trial. Otolaryngol Head Neck Surg 2004;130(3):291-9.

11) Powell NB, Riley RW, Troell RJ, Blumen MB, Guilleminault C. Radiofrequency volumetric reduction of the tongue. A porcine pilot study for the treatment of obstructive sleep apnea syndrome. Chest 1997;111(5):1348-55.

12) Emery BE, Flexon PB. Radiofrequency volumetric tissue reduction of the soft palate: a new treatment for snoring. Laryngoscope 2000; 110(7):1092-8.

13) Woodson BT, Nelson L, Mickelson S, Huntley T, Sher A. A multiinstitutional study of radiofrequency volumetric tissue reduction for OSAS. Otolaryngol Head Neck Surg 2001;125(4):303-11.

14) Woloszko J, Gilbride C. Coblation technology: Plasma-mediated ablation for otolaryngology applications. Sunnyvale, CA: Arthrocare Corp;2000.

15) Rhee CS, Kim DY, Won TB, Lee HJ, Park SW, Kwon TY, et al. Changes of nasal function after temperature-controlled radiofrequency tissue volume reduction for the turbinate. Laryngoscope 2001;111(1):153-8.

16) Coste A, Yona L, Blumen M, Louis B, Zerah F, Rugina M, et al. Radiofrequency is a safe and effective treatment of turbinate hypertrophy. Laryngoscope 2001;111(5):894-9.

17) Lin HC, Lin PW, Su CY, Chang HW. Radiofrequency for the treatment of allergic rhinitis refractory to medical therapy. Laryngoscope 2003; 113(4):673-8.

18) Bäck LJ, Hytönen ML, Malmberg HO, Ylikoski JS. Submucosal bipolar radiofrequency thermal ablation of inferior turbinates: a long-term follow-up with subjective and objective assessment. Laryngoscope 2002;112(10):1806-12.

19) Wolfswinkel EM, Koshy JC, Kaufman Y, Sharabi SE, Hollier LH $\mathrm{Jr}$, Edmonds JL. A modified technique for inferior turbinate reduction: the integration of coblation technology. Plast Reconstr Surg 2010; 126(2):489-91.

20) Lee JY, Lee SW, Shin JM, Kim HJ, Kim KH, Byun JY, et al. Comparative study on the long-term effectiveness between coblatorand microdebrider-assisted partial turbinoplasty. Korean J Otolaryngol-Head Neck Surg 2006;49(5):510-6.

21) Smith TL, Smith JM. Electrosurgery in otolaryngology-head and neck surgery: principles, advances, and complications. Laryngoscope 2001;111(5):769-80

22) Organ LW. Electrophysiologic principles of radiofrequency lesion making. Appl Neurophysiol 1976-1977;39(2):69-76. 
23) Di Rienzo Businco L, Di Rienzo Businco A, Lauriello M. Comparative study on the effectiveness of Coblation-assisted turbinoplasty in allergic rhinitis. Rhinology 2010;48(2):174-8.

24) Lin HC, Lin PW, Friedman M, Chang HW, Su YY, Chen YJ, et al. Long-term results of radiofrequency turbinoplasty for allergic rhinitis refractory to medical therapy. Arch Otolaryngol Head Neck Surg 2010;136(9):892-5.

25) Sapçı T, Güvenç MG, Evcimik MF. Radiofrequency treatment for inferior turbinate hypertrophy. Kulak Burun Bogaz Ihtis Derg 2011; 21(1):56-60. 